ББК: 85.118 .7

A43

DOI: $10.18688 /$ aa199-1-11

Th. N. Howe

\title{
The Development of Panoramic Sensibilities in Art, Literature, Architecture and Gardens in the Villas of Rome in the Late Republic and Early Empire: The Perspective from Stabiae
}

\section{The Borderless World of the Late Hellenistic Mediterranean Elite ${ }^{1}$}

The immense proliferation of Roman luxury villas (villae maritimae) around the Bay of Naples seems to have accelerated rapidly after the Social War of 91-89 B.C. and Pompeius' suppression of piracy in 74 B.C., so much that by the time Strabo was writing in about 9 B.C. the area was...

"...strewn, in part with these cities... and in part with residences and plantations which, following in unbroken succession, present the aspect of a single city". (Strab., 5.4.8)

The process of increasing the luxury of townhouses in Rome (domus) and villas in the Bay of Naples, accelerated in the last decades of the Republic and coincided with the most ferocious senatorial political competition ${ }^{2}$, and villas and outward signs of Greek culture were new tools of political competition.

"In 78 B.C. there was no finer house in Rome than that of Lepidus, but only thirty five years later it was not even in hundredth place" (Plin., NH, 36.109).

But after about 30 B.C., at the end of the Civil Wars, to about A.D. 60 - with the virtual end of senatorial political competition - another development takes place: the Roman elite and their artists and architects created a unified multi-media environment in their villas which unifies painting, poetry, architecture, and garden design to views of nature. Why?

Villas acquire outward facing panoramic colonnades with Greco-Roman monumental "orders," façades are punctuated by pavilions with symmetrical façade units hieratically dominated by the center (i.e., the "B-A-B" motif common to Renaissance and Baroque architecture), they abandon the Durchblick straight passage from entrance to atrium for surprising transitions between spaces (including gardens), each with independent cross-axial multiple framed views. This occurs at the same time as the dreamlike spindly architectural fantasies of the Pompeian Third Style and picturesque architectural landscape vignettes of seaside villas are invented, and poets such as Virgil and Ovid introduce Latin bucolic or pastoral poetry.

The author expresses great gratitude for being invited to present these ideas in this conference, and warm thanks for the special efforts to show participants the fabulous wonders of this great capital city and the region.

2 Recent publications: [20; 34]. 
The invention of the Roman villa was a distinctly Roman accomplishment, though like the computer innovations of Steve Jobs - it was a matter of aggressive borrowing and re-synthesizing [22, pp. 13-46, 199-222; 38, pp. 1-24, esp. p. 3]. It was a phenomenon of a borderless Hellenistic world that came into existence after mid- $2^{\text {nd }}$ century B.C. But the process of increasing monumental ostentation in Roman public architecture started earlier, as early as the early $3^{\text {rd }}$ century B.C. ${ }^{3}$, and then, most particularly after the Third Macedonian War and the battle of Pydna (168 B.C.), which more or less ended Macedonian Greek independence, particularly when Delos was made into a free port in 166 B.C. Merchants came from all over the Mediterranean: Syria, Phoenicia, Egypt, Cyprus. A particularly large number came from Campania, the area of the Bay of Naples. Campania's great commercial wealth and artistic production largely dates after that time. The House of the Faun in Pompeii is an early example (c. 150 B.C.), and is as large as any archaeologically known Hellenistic royal palace (excepting probably Vergina).

From that point on -168 and 166 B.C. - the central and eastern Mediterranean was essentially one world, at least for the elites: the senatorials and the Near Eastern client kings that they mingled with (including Herod the Great and Cleopatra VII) lived in a cosmopolitan world. And one of the first to recognize the political usefulness of adapting Greek cultural forms to political presentation may have been the victor of Pydna himself, L. Aemililus Paullus:

Volgo dictum ispsius ferebant, et convivium instruere

Et ludos parere eiusdeum esse qui vincere proemio sciret

"A saying [of L. Aemilius Paullus, the victor at Pydna in 168 B.C.] was commonly repeated, that a man who knows how to conquer in battle should also know how to give a banquet or organize the games". (Strab., 45.32.11)

In 16 B.C. Herod the Great invited M. Vipsanius Agrippa (Augustus' lifelong right-hand man) to visit Judea and examine his new and innovative architecture at Sebaste, Caesarea, Alexandrium and Herodium; the next spring Herod followed Agrippa to tour the architecture of Asia Minor (Jos., AJ, 16.13-15; 25, p. 13). The elite of this world, post-Pydna, and their staffs of artists and secretaries, lived in a world without borders.

\section{The Chronology of the Development of Panoramic Composition}

Greek temples have a highly assertive exterior aspect when viewed from afar. In the $6^{\text {th }}$, $5^{\text {th }}$ and $4^{\text {th }}$ centuries, monumental "complexes" - buildings that are assemblages of volumes around a dominant temple-like volume, like the Athenian Propylaia - are rare. Temples and stoas tend to be single volume compositions, "simplexes," articulated with external orders on at least one side.

On the other hand, Greek houses, or even mansions, or such mansions as could be called palaces, seem to have had very little "assertive exterior" monumental aspect, such as exterior porches, symmetrical composition around a dominant form, or colonnades with monumental orders or pediment, or at least as far as we can know (the exception again may be Vergina

\footnotetext{
Arguably the Temple of Victoria on the Palatine [7, p. 31; 8, p. 44].
} 


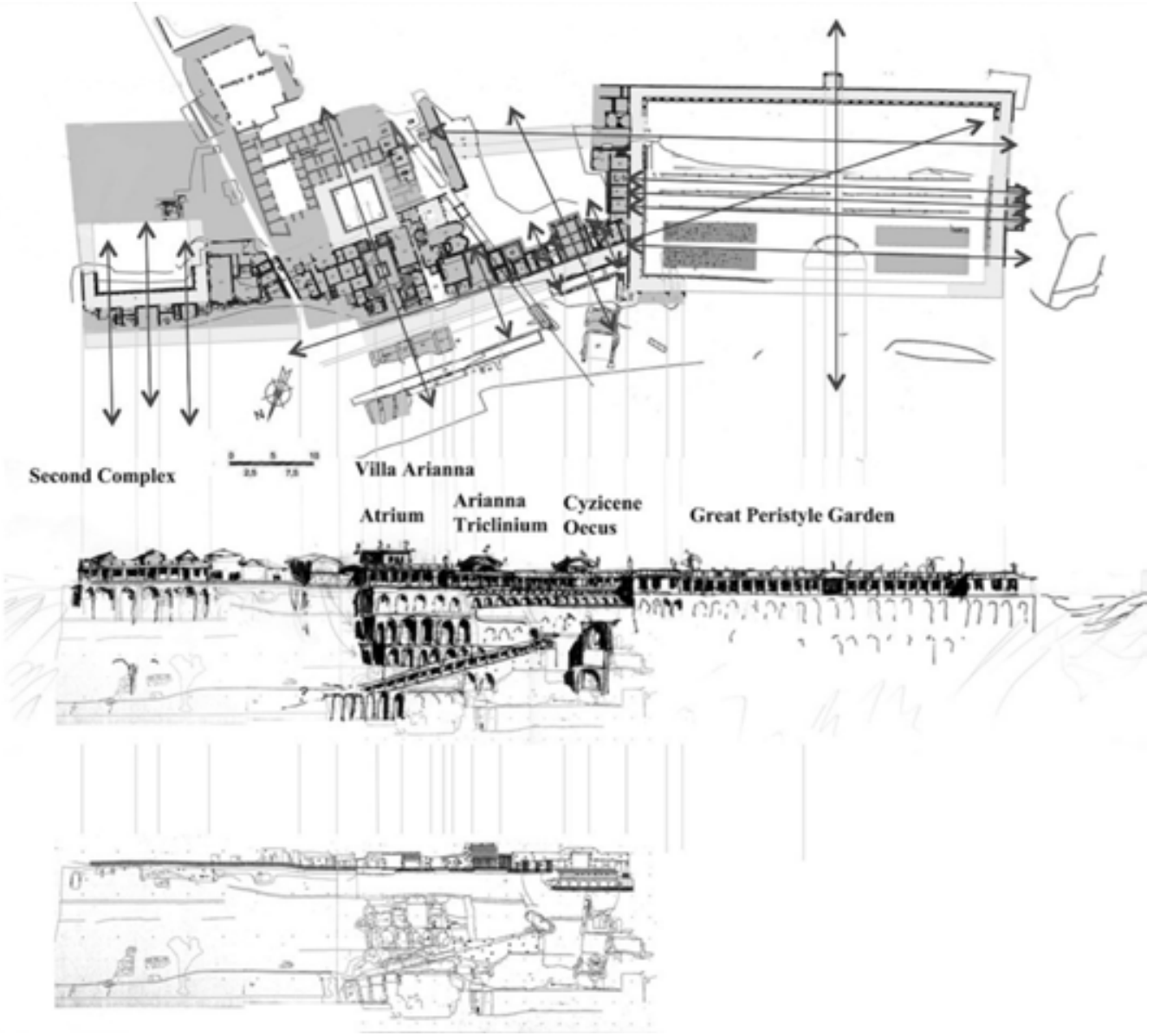

Fig. 1. T. N. Howe, Reconstruction and plan of the Villa Arianna and Second Complex as C. A.D. 60; view directions shown by arrows, movement patterns by dotted lines. RAS Foundation

[26, pp. 81-84; 27, fig. 1; 28, fig. 17]). If the House of the Faun at Pompeii, or the "palaces" on the acropolis at Pergamon are the best we can know what those on the Akre at Alexandria looked like in the mid- $2^{\text {nd }}$ century B.C., they were pretty dull... from the outside: basically a wall on a street with a small door, maybe framed by pilasters and a flat pediment, and leading to a square colonnaded courtyard on the inside. The inward looking interior courtyard surrounded by a uniform seems to have been the main feature of the Hellenistic palace.

But by the time of the later phases of the villas of Stabiae, Oplontis and the Papyri (mainly post 30 B.C.), the newer villas on the Bay of Naples begin to be built, or the older ones modified, with seafronts with panoramic external colonnades on high platforms (bases villae) visible from afar [38, p. 41], punctuated with three-, five-, seven- and even nine-part symmetrical compositions around a dominant pavilion (e.g., Stabiae, Villa Arianna, Second Complex, Fig. 1), and framed views of nature from the villas. They begin to look a lot like - as 


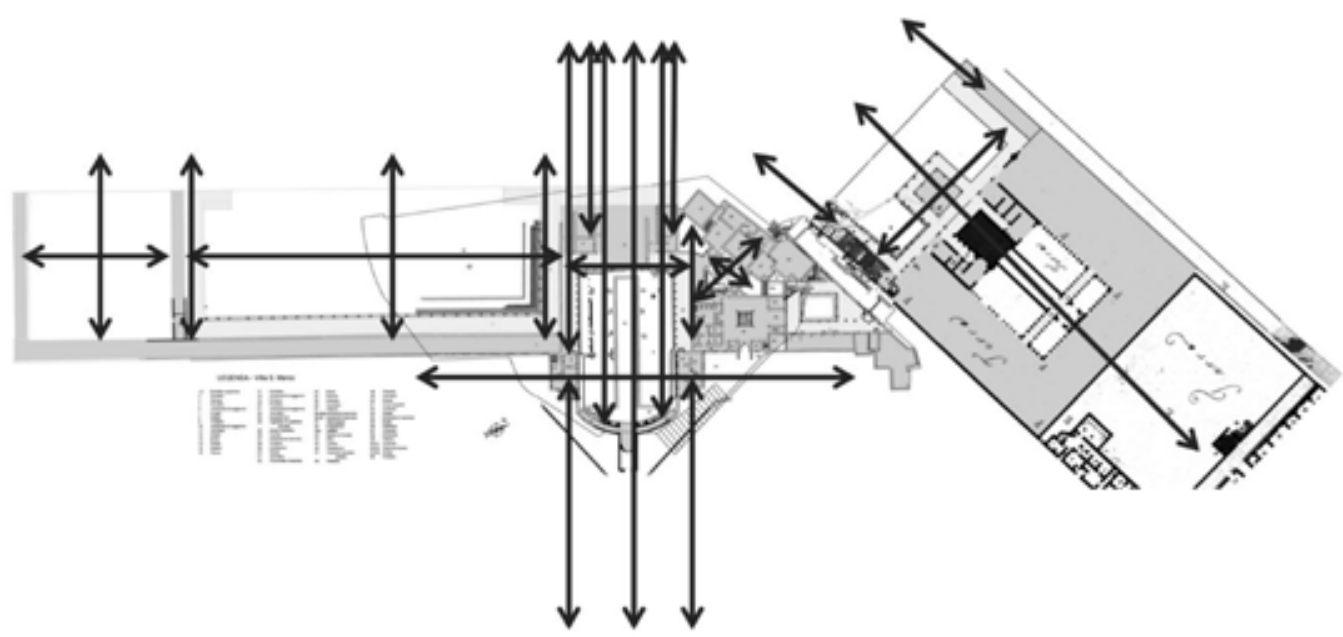

Fig. 2. Plan of the Villa San Marco and the Adjacent Townhouse ("Panoramic" domus); view directions shown by arrows, movement patterns by dotted lines. RAS Foundation

far as we can reconstruct them - the picturesque painted vignettes of seaside villas/palaces supposedly invented by one "Studius" in c. 30 B.C. (Plin., NH, 35.116-117) and represented by numerous architectural frescoes at Stabiae, especially at the Villa San Marco, and the actual probable appearance of the Villa Arianna (Fig. 1, Fig. 2, Fig. 3).

The chronology of the development of the panoramic monumental complex in the Hellenistic period appears to have been very rapid $[12 ; 13 ; 16]$, concentrated in the period from mid- $3^{\text {rd }}$ to mid- $2^{\text {nd }}$ centuries B.C. After mid- $2^{\text {nd }}$ century (the battle of Pydna and the conquest of Macedonia and the siege of Corinth in 168/148/146) the main center of creativity in such architecture moves from the Hellenistic East to Rome. Talent followed money.

The development occurs in approximately three stages after the preliminary monumentalization of the Greek temple and stoa c. 600-400 B.C.:

0 . The development of panoramic complex with assertive columnar exterior aspect is basically the adaptation of the highly exterior aspect of a single-volume Greek temple. A monumental building articulated by exterior colonnades is a feature that actually is very rare in world architecture before the Greek temple, e.g. Deir el Bahri, Neo-Hittite bit-hilani [26, pp. 35-72]. The other preliminary development is the stoa, an assemblage of long single-volume units, but so long that they are less perceived as a volume, and more a linear space boundary; in other words, they control spatial units more than form mid-space volumetric units. By c. 400 virtually all forms of stoas were known in Athens: one-storey, two-storey, one-aisle, two-aisles, L-stoas, pi $(\pi)$-stoas, stoas with pedimented wings; full courtyard stoas (i.e. colonnaded courtyards) [5, pp. 39-54].

1. The development of large colonnaded complexes with hierarchical composition around a dominant form or axis begins in Ptolemaic Egypt in the reigns of Ptolemy II (281-246 B.C.) and III (246-221) under the influence of New Kingdom axial courtyard temples. The first Greek temple that was completely enveloped by colonnades is the Serapeion at Alexandria (283-246 B.C.) [23, pp. 53-55] and the first with the temple on-axis within the entrance to the colonnaded courtyard is the dynastic sanctuary of Ptolemy III and Berenike II at Hermoupolis 


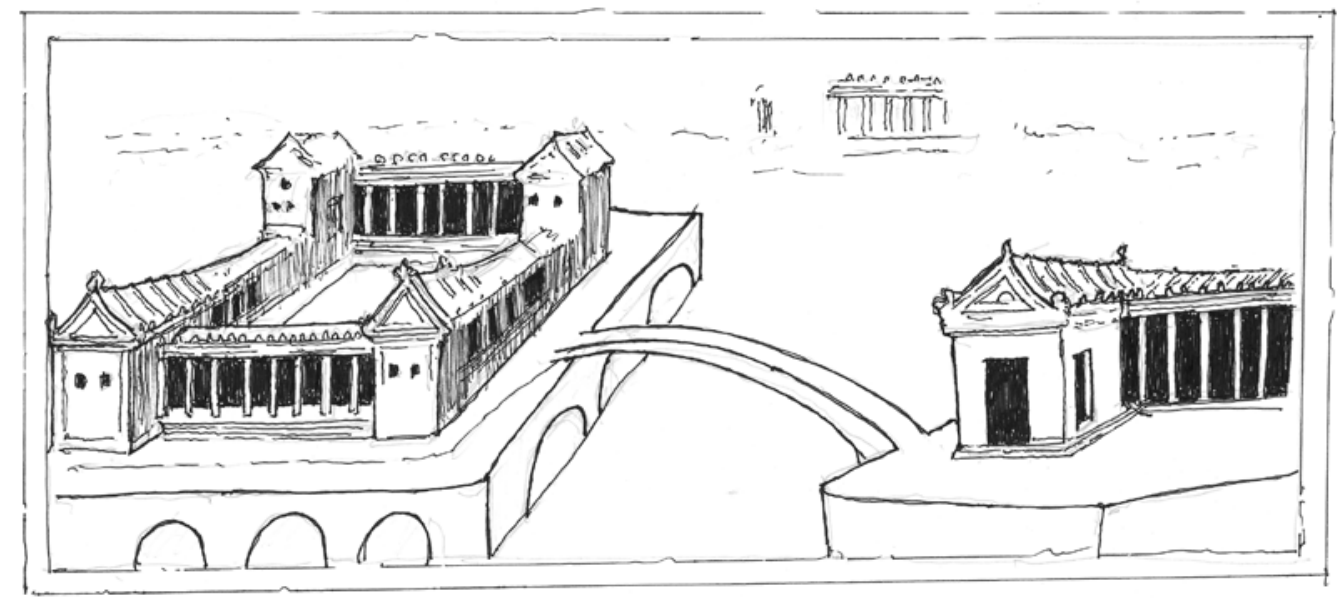

Fig. 3. Stabiae, Villa San Marco, Room 50, Vignette of a Seaside Villa, c. A.D. 50? MANN 4286, redrawn by $\mathrm{T}$. N. Howe

Magna (246-222 B.C.) [23, pp. 56-58]. By the later $3^{\text {rd }}$ century and into about the mid- $2^{\text {nd }}$ century colonnaded courtyard complexes, which were usually closed to any external view, proliferated in mainland Greece ${ }^{4}$ and especially Ionia ${ }^{5}$, always with a temple as the dominant feature, and sometimes with the axial temple embedded in the stoa of one side and aligned with a propylon with a temple front ${ }^{6}$.

The exceptions were a number of courtyard complexes associated with Pergamon in the early $2^{\text {nd }}$ century which opened to the view and were visible from afar with either stoa on a high podium ${ }^{7}$ or L- or $\pi$-shaped stoas open to the view from a height ${ }^{8}$. These sanctuaries are often not initially planned at once as unified complexes ${ }^{9}$ but stoas are often added incrementally and develop the symmetrical composition around a dominant accent over time; the sanctuary at Kos originally had two terraces closed to any view toward the sea until in the mid- $2^{\text {nd }}$ century a third higher terrace and a Doric peripteral temple framed by a $\pi$-stoa was built fully visible open to the view and gave the sanctuary an assertive columnar aspect with a dominant (the Doric temple) from a distance [11, pp. 401-410]. Another nascent tendency that develops in the late $3^{\text {rd }}$ or $2^{\text {nd }}$ century is for there to be a pronounced cross-axis which is occasionally shorter than the main axis ${ }^{10}$. This becomes a major feature in Roman Imperial architecture.

\footnotetext{
$4 \quad$ Messene: [5, pp. 256-258].

5 Miletos, Priene, Lindos, Kos, Magnesia: [5, pp. 258-261, 277-279, 251-252, 246, 253-254].

$6 \quad$ Priene, Zeus Sanctuary; Miletos, North Market: [5, pp. 278-279, 259].

7 Agora of Assos: [5, pp. 218-219].

8 Pergamon, Athena sanctuary; agora of Assos; Lindos; the last phase of Kos: [1, pp. 70-74; 4, pp. 219-229, 251-252, 246, 248-252; 16, p. 197; 11, pp. 401-408, 410-421, 421-440].

$9 \quad$ Gruben suggests that although the upper and lower propylaia are of different dates they may follow a single coordinated panoramic design because of the correspondence of entablature heights [11, 410-421].

10 Miletos, North Market, by 150 B.C.; Lindos, late $3^{\text {rd }}$ century; Delos, Syrian Divinities, by c. 100 B.C.: [5, pp. 251-252, 259; 18, pp. 165-166, ill. 269].
} 
Monumental construction seems largely to have ceased in Greek lands after their incorporation into Roman provinces (146, 133 B.C.) once they were ruled by extortionist senatorial governors and equestrian tax farmers ${ }^{11}$.

2. After the battle of Pydna (168) and the siege of Corinth (146) the victorious Roman senatorial commanders (viri triumphales) brought back with them the full repertoire of what had just been developed in the previous decades in the new panoramic architecture of Greece, Ionia and Alexandria, and apparently a fair number of their craftsmen, and even their marble. The flurry of porticus built in Rome after the end of the Second Punic War in 201 by several censors were probably utilitarian structures with timber [31, pp. 20-31], non-monumental colonnades. The Roman basilica was also probably invented about this time as an evolution of an atrium house [37]. The first truly monumental porticus built in Rome by a vir triumphalis was the Porticus Octavia built by C. Octavius, the fleet commander during the Pydna campaign, and it was a porticus duplex facing the Circus Flaminius with Corinthian capitals in gilded bronze. As a porticus duplex it probably was open to the Circus ${ }^{12}$, hence a "panoramic" feature of the Circus, which otherwise had no architecture. From 146 a succession of large completely symmetrical porticus sanctuaries with axial temples framed by courtyard or $\pi$-porticus, open to the view and visible from afar, are built: the porticus Metelli (146), a full courtyard but with open front colonnade framing two temples, one pre-existing, the other, Iuppiter Stator, new, the first marble temple in Rome, designed by the Greek architect Hermodoros of Salamis; the "theater" sanctuaries of Tibur (c. 140, by the same architect?), Gabii (post 150?) and Praeneste (c. 130) (Fig. 4), and the Italic style temple surrounded by a pi $(\pi)$-porticus at Minturnae (post 191$)^{13}$. The Corinthian temple

\footnotetext{
$11 \quad$ Not generally noted: [21, pp. 158-168].

12 The term is ambiguous and could mean a two-aisled porticus, a two-storey porticus or a two-winged porticus, i.e. an L-stoa. Senseney suggests the latter and puts forward the idea that it imitated the North-East L-stoa in the Athena Sanctuary of Pergamon, which would have been one of the first panoramic precincts fully open to and from the view. It asymmetrically framed the pre-existing Athena temple which was not on axis [30, pp. 421-444].
}

$13 \quad[13 ; 7 ; 8$, pp. $128-129 ; 5$, pp. 261-262]. 
of Iuppiter Anxur at Terracina (early $1^{\text {st }}$ century?) is not an axially symmetrical composition (the temple is placed obliquely on a high opus incertum substructure high on a soaring seaside cliff, but backed by a single porticus, and a $\pi$-porticus further behind) but clearly makes a spectacular impression on the panorama of the town ${ }^{14}$. Praeneste, a product of the local, not senatorial, aristocracy, is clearly the piece de resistance of virtuosic composition, with seven terraces, all with different motifs, free-standing and engaged pilaster colonnades punctuated with pavilions and a single axis leading to a dominating feature: a theater-colonnade. And it aggressively opens to the view to be viewed from afar, and exploits the slope and the differential cross-axes, with the main axis being the shorter (Fig. 4) [13].

An essential technical innovation of the $2^{\text {nd }}$ century B.C. in Rome that permitted the development of these sanctuaries and later villas on high platforms and cliffs was the arcuated concrete (opus incertum) retaining wall [38, p. 20].

The axial/cross-axial sanctuary of a temple on axis in a colonnaded courtyard becomes the model of the new Roman fora built in Rome in the late $1^{\text {st }}$ century B.C. and $1^{\text {st }}$ century A.D.: Caesar, Augustus, Nerva,Vespasian (Pace), Trajan. But, ironically, these are all closed interior isolated spaces, and are almost invisible inside the city. Far from being "panoramic", seen from afar, they instead exploit startling transitions from one isolated forum to the next; the axes and cross-axes function only within the individual fora. The same thing occurs in the villas of Stabiae in the early Imperial period.

3. During the tremendous upsurge in vicious political competition which followed the Social War of 91-89 many of these architectural devices are transferred to villa architecture, presumably built by the senatorial elite, but not exclusively so [38, pp. 1-25; 22, pp. 13-47, esp. p. 17; 15]. It is hard to reconstruct their external appearances but they seem to have exploited locations with height (for visibility from afar, e.g. the villa of Lucullus on the Pincio in Rome) and views (for the pleasure of inhabitants and guests). Composition, however, involved the massing of building volumes with roofs and windows rather than colonnades, or with small porches. But often compositions have an axial "Durchblick" from entrance court to atriumwith-a-view. Volumes are massed symmetrically in three-, five- and seven-part compositions. The villa of Lucullus (68-63) overlooking the Campus Martius (where he waited for five years to organize his triumph) had a main unit organized around an enormous exedra opening to the Campus. It definitely could be "seen from afar" and created a "panorama" of its own. The Villa of the Papyri, now dated to c. 50 B.C. rather than 150 [10, pp. 441-465], was considerably more modest, and was a seaside platform villa (basis villae) on an arcuated podium (a miniature version of the temple of Iuppiter Anxur at Terracina). From the exterior the volumes are a three-part symmetrical composition dominated by the volume of the sea-view exedra. These might be called "overlook" villas since their intention was to exploit the view from a height, and to be seen from afar, and thus to be expressions of patronal political power.

Another cultural occurrence which is contemporary with the probable political pressure to monumentalize the elite villa is the arrival of the Pompeian Second Style of wall painting c. 80 B.C., just after the Social War. It is a style which develops syncopated three-, five-, sevenpart columnar symmetrical compositions in screens of orders focused on a central object 
in front of parapets which partly blocked views to gardens. There is no question that this too comes from real (i.e. constructed) fantasy screen architecture developed in Alexandria for tombs and royal pavilions in the course of the $2^{\text {nd }}$ century B.C. and is represented in the great tomb facades of the desert trading emporium of Petra, probably in the $1^{\text {st }}$ century B.C. (i.e. Al-Khazneh) ${ }^{15}$.

4. After approximately 30 B.C., or as early as 50 B.C., there is a new change. It is more or less contemporary with the political environment post-Actium (31 B.C.).

Virgil's Eclogues are written between about 44 and 30 B.C. As mentioned, one Studius seems to "invent" vignettes of picturesque seaside vignettes about 30 B.C. (Fig. 3). The Pompeian Third Style appears, abandoning the faux-marble monumentality of the Ptolemaic Second Style ${ }^{16}$ for a fantasy world of spindly reed-columns and flattened walls which nonetheless open to large framed images of nature. About the same time or slightly earlier (c. 50 B.C.?) one sees the appearance of a new type of elegiac lyrical painting with deep fluid space in which there is no clear precedent in Hellenistic painting: the "Odyssey Landscapes". Humans are dominated by nature, painting features bravura fluid brushstrokes, there are fluid spatial perspectives, and adumbrated active light and atmosphere. The ideal of the bucolic poetry of Virgil and Ovid is that there is a simpler life closer to nature that is superior to and more moral than the current one of political engagement. It is an odd mix of fascination with supposedly simple pleasures of nature and an aesthetic preference for intense artificiality and increased spatial control.

The connector may be that the political elite is retreating into a life of "leisured resistance" [9, pp. 1-25, esp. p. 20]. The political elite (senatorials and municipales) sought to assert an illusion of their freedom - at least in the absence of Caesar - by creating in their villas a fantasy world where they controlled views, nature and human movement in the midst of architecture that looked slightly like an elegiac dream palace.

This also may be why apparently largely only after 30 B.C. numerous seaside villas and domus on the Bay of Naples acquire panoramic colonnades with motifs borrowed from the picturesque colonnaded stoas or porticus framing Hellenistic monumental architecture ${ }^{17}$. They commonly feature complicated hierarchical compositions incorporating compositionally dominant pavilions - often with fastigia (pedimental temple-fronts) and rest on arcuated concrete substructures. The winged seaside and landside porticus of Oplontis are apparently later additions c. 30 B.C. and are remarkably similar to the lower winged stoa at Lindos of a century earlier (c. 150 B.C.). Three of the villas of Stabiae (c. 30 B.C. - c. A.D. 30 ?) [13; 14, pp. 108-113] feature large $\pi$-shaped peristyles the size that Vitruvius recommends for public palaestrae (two stades - Vitr., 5.11.1-4), and recall the panoramic open-view $\pi$-stoas backing temples on platform sanctuaries such as Gabii, Tibur, Praeneste, Minturnae and Kos [16]. Note that the Villa of the Papyri, a bit earlier (c. 60 B.C.), also features a large peristyle court parallel to the sea front... but the difference is that it is closed to the view [38, pp. 28-45].

$15 \quad[23$, pp. $40-41,49]$, terminus ante quem $1^{\text {st }}$ century B.C.

16 On considering the function of the Second Style, Mckenzie suggests that because "Romans regarded Egypt as a paradisal garden in which the gods once dwelt," they regarded Alexandrian architecture as suited to suggesting the paradisal character that they sought in their villae maritimae [22, pp. 96-112].

17 On the downdating of additions to Oplontis: [38, pp. 45-50]. 
Although the main basis villa section of the Villa of the Papyri features a somewhat rustic partial wrap-around porch on a high platform, it seems reasonable to propose that the real development of panoramic colonnades and pavilions on the exterior of Roman elite domestic architecture is largely a phenomenon of post-Actium (31 B.C.). This seems to apply also to the narrow-front townhouses (domus) built after Actium on the out-of-use town sea walls in Pompeii, Herculaneum (e.g. house of the Stags, House of Diana) and also Stabiae (Panoramic Domus [3] and Second Complex, Figs. 1 and 2) [14, pp. 108-113]. It seems to apply also even to more modest rustic villas like Settefinestre, which acquired its cryptoporticus and porch in the later $1^{\text {st }}$ century B.C.

The phenomenon of enhancing an elite villa by external panoramic colonnades seems to be Mediterranean wide about this time. Herod's palaces at Masada and Caesarea Maritima date to the decade after Actium and feature spectacular external colonnades on platforms, often with central convex colonnaded exedrae. Tiberius' later spectacular Villa Iovis on Capri - a one-storey colonnade punctuated by high, projecting colonnaded pavilions, all perched on an enormous substructure on a 1000 foot cliff - clearly follows the breathtaking precedents of Masada and Caesarea [12; 13; 25, pp. 11-12]. This was the arrival of palatial architecture meant to be seen from afar, like a distant architectural dream in a romantic painting. And Herod's architecture was as much a part of this new world as was Herod a part of the society of the new Imperial international elite.

\section{The Evolution of Panoramic Colonnades and Differential Cross-Axial Views at Stabiae}

In the later Republic, during the so-called senate holidays (supposedly April and October - November) the capital virtually moved from Rome to the senatorial villas of the Bay of Naples. But Stabiae was not the most important collection of villas of the powerful of the late Republic and early Empire. Those villas clustered on the other side of the Bay of Naples around Puteoli, Cumae, Baiae and Misenum. Cicero, the Cornelii, Marius, Sulla, Agrippina the Elder, Lucullus, Pliny the Elder and many others had country seats there [6, pp. 18-73]. But today, they are very poorly preserved. The main value of Stabiae is that it is only here that can we get an idea of the probable spatial arrangement of these villae maritimae: a series of enormous villas clustered directly beside each other on the brink of a seacliff, often with private access to a mole (dock). Few reconstructions have been attempted to portray what they looked like from afar (Fig. 1), but their shining white colonnades - even if marble stucco - cresting along the whole length of the hill must have been spectacular from afar, easily visible from Pompeii.

Most, perhaps all, of the plateau above the seacliff at Stabiae was originally farmland before the Social Wars (91-89 B.C.), when the town was razed by L. Cornelius Sulla (89 B.C.). According to Pliny, the entire area afterward was then rebuilt as villas (ad villam adibiit). The current remains of the town are apparently rebuilds as well (Plin., $N H, 3.9 .70$ ).

The earliest construction at the Stabiae villas is the core of the Villa Arianna, apparently a conventional "Vitruvian" peristyle-and-atrium villa (Vitr., 6.5.3) like the villa of the Mysteries, with a single passage from entrance through court to atrium to view, the so-called Durchblick, "through-view". It is dated at the moment only by early Second Style frescoes in four rooms near the atrium, therefore c. $80 / 60$ B.C. The "Durchblick" is perpendicular to the line of the shore and probably only a couple of the cubicula and the tablinum of the atrium had sea-views. The 
Villa at this stage would have been comparable to the Villa of the Mysteries: from the seafront, the Mysteries Villa had a projecting semi-circular exedra (in the position of the tablinum of a domus) with large viewing windows, and two flanking rooms with large windows, one of them being the famous Mysteries Chamber. There was a porticus to one side but probably not on the front. The Villa Arianna rested on a much higher substructure, the cliff rising a good c. $50 \mathrm{~m}$ above sea level, and may have had no private access to the sea at this time. The shoreline, whose location is still unknown, was perhaps $100+\mathrm{m}$ away from the foot of the cliff.

Most of the construction at Stabiae is "Augustan" or later, perhaps built with the intent of clustering close to Augustus' supposedly twelve villas on Capreae (Capri) and others at Surrientum (Sorrento) [2, pp. 380-382; 12; 14, 108-113]. Stabiae thus might preserve the urbanistic pattern likely to have prevailed in the later Republic both in Rome and Baiae: dense clusters of elite villas side by side on the edges of high panoramic ridges. Under the Empire, with the decline of the political life of the elite, the domus in Rome are widely scattered, and so apparently eventually are country villas ${ }^{18}$.

There is a radical change in the new large villas which are laid out at Stabiae in the early Augustan period (the Villa San Marco and the Villa del Pastore) and those which are modified (the Villa Arianna and the townhouse-like Second Complex, and the Panoramic Townhouse in the pagus of Stabiae ) (Figs. 1,2).

Villa San Marco is laid out parallel to, not perpendicular to, the sea-coast view, giving far more rooms access to a sea-view, which was, and still is, spectacular, all the way to Vesuvius and Naples. Interestingly, none of the seaview rooms are private cubicula; this is different in the Villa Arianna renovations where many of the cubicula have sea and mountain views. The Villa San Marco is approached from the street of the rebuilt town/pagus of Stabiae through a traditional peristyle-and-atrium sequence, but unconventionally the approach leads not to a Durchblick with a view, as at the Villa of the Mysteries or Villa Arianna, but dead-ends at a remarkable lararium in a niche. The passage through the villa is not through a linear Durchblick from front to sea-view, but through a zigzag path with surprising transitions between large spaces. The spaces tend to be self-contained with strong cross-axial accents ${ }^{19}$. They also often have multiple front-back or left-right cross-axial views to distant prominent landscape features, such as Naples (Neapolis), the Appenines, the Monti Lattari, the Sorrento peninsula (Fig. 2).

There is a major renovation in the Villa San Marco c. A.D. 60 (Fig. 2) [2, pp. 380-382]. The huge triclinium flanked by other triclinia dates to this phase and forms a five-part frontal composition (unclear whether fronted by a porticus) with a front view to Naples and a rear view to the Monti Lattari. The nymphaeum at the back of that same axis, which frames also a mountain view to compliment the view in the other direction of the Gulf and Naples, is a multimedia extravaganza with an apse with a segmental curve and featuring architecture (engaged

$18 \quad[15 ; 32$, vol. 2, pp. 22-217] s.v. domus. Overall, some 510 domus and their owners' names are known and listed in the LTUR although not all can be located or connected with identifiable remains. In many cases it cannot be known if the named owner was of senatorial status: but this number includes houses which are mentioned twice as they pass between owners, and such public structures as the Domus Publica.

19 As noted above, the same pattern of abrupt transitions between cross-axial spaces prevails in the new urban fora of Rome from the 50s B.C., though without the framed views to the outside, or the visibility from afar. 
arcade), water (deep pool and jets), Fourth Style stucco (figures framed in architecture), vitreous mosaic (scenes of Phryxis and Helle, and the Rape of Europa), fresco (figures), and alabaster sculpture (a krater). Its model, again, comes from Egypt: a small fountain house dedicated possibly to Arsinoe II, wife of Ptolemy II, described in an epigram of Poseidippos, as a semi-circular vaulted apse with figures inserted into the bays of engaged columns facing a pool [23, pp. 61-62]. It may be the earliest example of the type of multi-media ensemble in Roman architecture that leads to the Canopus of Hadrian's Villa.

And facing either side of nymphaeum are so-called diaetae ("day-rooms") with vast windows opening to triple views: to the nymphaeum, the Monti Lattari and the Appenine (to the NE) or Sorrentine (to the SW) mountains.

After this spectacular courtyard, enclosed but with framed views, there is an abrupt transition to an enormous $\pi$-peristyle on a platform opening (apparently) to the view toward Naples. And in 2001/2006 the RAS Foundation and Soprintendenza Pompei discovered yet a third courtyard [3].

The Villa Arianna is modified with numerous additions also now laid out parallel to the coast, and a ramp descending under the villa to the shore, probably a private access (Fig. 1). The additions are in units, added in sequence form $\mathrm{E}$ to $\mathrm{W}$ : a large sea-view triclinium; then a seven-part symmetrical cluster around an airy true "Cyzicene" oecus (Vitr., 6.3.10), all fronted by a colonnade and seven terraces, one with fictive "battlements;" and finally, an enormous garden (tentatively laid out c. A.D. 30) framed by a $\pi$-peristyle and clearly open to the view of Vesuvius. These apartments, gardens and dining rooms all introduce multiple views of gardens, sea and distant mountains, front and back, left and right (Fig. 1).

The RAS Foundation was able to excavate the huge $(30 \times 108 \mathrm{~m})$ garden of the Great Peristyle of the Villa Arianna, which was so well preserved that we were able to study the plantings of the garden in such detail that revealed that the garden architects ("topiarii") were also working with the same sensibility to framed panoramic views and differential cross-axial spaces as architects were developing (Ill. 16) [14]. It was a "strolling" garden, an ambulatio, which was meant to give the visitors the same experience of space and cross-axial framed views as the architectural spaces of the villa itself. The plants shaped the spaces of the garden in the same way as the buildings, with cross-axial views. And in this case the main axis of the garden (toward Vesuvius) was the shorter one, a common feature in later Roman architecture, one suggested by some earlier Hellenistic and Republican sanctuaries, as mentioned above (the Sanctuary of the Syrian Divinities at Delos).

The garden appears to mark the arrival in our archaeological evidence of the landscape architect (topiarius) ${ }^{20}$ in Roman architecture.

If this chronology is correct, the absorption of motifs of "panoramic sensibilities" from the Hellenistic world (including the Hellenistic Near East) may have begun as early as the 290s B.C. in monumental architecture in Rome [7, p. 31; 8, p. 44], but dates largely after 166 in public buildings and mansions; but the multi-media synthesis achieved in the villas of the Bay of Naples like those at Stabiae is contemporary with the loss of independent political power by the Roman senatorial elite post 31 B.C. 
The suggestion here is that the remarkably coordinated phenomenon that occurs contemporaneously in seaside (or hilltop) villas from the Bay of Naples to Judea, of picturesque external colonnades on high platforms, Third Style wall painting, elegiac landscape painting, bucolic poetry, movement through sudden transitions between architectural spaces with strong cross-axial composition and framed views of nature, and "strolling gardens" with similar cross-axial spaces and views that control the movement of guests... is an environment meant to shelter the elite from a new Imperial autocracy from the loss of their independent political power, with the illusion of a fantasy environment where they control people, nature and public architecture... just after they have in fact lost control to Caesar of real people, actual nature and public architecture.

\section{References}

1. Akurgal E. Ancient Civilizations and Ruins of Turkey. Istanbul, Haşet Kitabevi Publ., 1978. 520 p.

2. Barbet A.; Miniero P. (eds.). La Villa San Marco a Stabia. Centre Jean Bérard, École Française de Rome, Naples, Rome, Pompei, Soprintendenza archeologica di Pompei Publ., 1999. 410 p. (in Italian).

3. Bonifacio G. Ufficio Scavi di Stabia. Castellammare di Stabia: indagini archeologiche nell'area del pianoro di Varano. Rivista di Studi Pompeiani, 2007, vol. 18, pp. 197-199 (in Italian).

4. Cicero (M. Tullius Cicero); Shackleton Bailey R. D. (trans.). Letters to Quintus and Brutus, To Octavian, Invectives, Handbook of Electioneering. Loeb Classical Library. Cambridge, Harvard University Press Publ., 2002. 496 p.

5. Coulton J. J. The Architectural Development of the Greek Stoa. Oxford, Oxford University Press Publ., 1976. 308 p.

6. D'Arms J. Romans on the Bay of Naples: A Social and Cultural Study of the Villas and Their Owners from 150 B.C. to A.D. 400. Cambridge, Harvard University Press Publ., 1970. 274 p.

7. Davies P. E. Rome and Her Neighbors: Greek Building Practices in Republican Rome. Ulrich R. B.; Quenemon C. K. (eds.). A Companion to Roman Architecture. Chichester, Wiley-Blackwell Publ., 2014, pp. 27-44.

8. Davies P. E. Architecture and Politics in Republican Rome. Cambridge, Cambridge University Press Publ., 2017. $366 \mathrm{p}$.

9. Dewar M. Leisured Resistance; Villas, and Politics in the Roman World. London; New York, Bloomsbury Publ., 2014. 144 p.

10. Esposito D. Pompei, Silla e la Villa dei Misteri. Perrier B. (ed.). Villas, maison, sanctuaires et tombeaux tardo-républicains: découvertes et relecteurs récentes, Actes du colloque international de Saint-Romain-enGal en l'honneur de Anna-Galina Zevi. Rome, Quasar Publ., 2007, pp. 441-465 (in Italian).

11. Gruben G. Die Tempel der Griechen. München, Hirmer Verlag Publ., 1976. 477 p. (in German).

12. Howe T. N. The Architectural Evolution at the Villas of Stabiae, c. 80 B.C. - A.D. 79. Yegül F.; Favro D. (eds.). Paradigm and Progeny: Roman Imperial Architecture and Its Legacy, Proceedings of a Conference Held at American Academy in Rome in Honor of William L. MacDonald, Dec. 6-7, 2011. Journal of Roman Archaeology, Supplementary Series, 2015, no. 101, pp. 63-78.

13. Howe T. N. Hellenistic Architecture in Italy: Consuetudo Italica. Miles M. (ed.). A Companion to Greek Architecture. Chichester, Wiley-Blackwell Publ., 2016, pp. 470-486.

14. Howe T. N. et al. Excavation and Study of the Garden of the Great Peristyle of the Villa Arianna at Stabiae, 2007-2012. Quaderni di Studi Pompeiani, VII. Associazione Internazionale di Amici di Pompei, Castellammare di Stabia, Longobardi Publ., 2016 (2017). 127 p.

15. Howe T. N. The Social Status of the Villas of Stabiae. Métraux G.; Marzano A. (eds.). Roman Villas in the Mediterranean Basin: Late Republic to Late Antiquity, Acts of an International Seminar at Mishkenot Sha'ananim, Jerusalem, December 16-17, 2008. Cambridge; New York, Cambridge University Press Publ., 2018, pp. 97-119.

16. Howe T. N. Hellenistic Greece, c. 400-430 BCE. Dykhoff T. (ed.). Banister Fletcher's A History of Architecture, $21^{\text {st }}$ edition, Ch. 17. London, Bloomsbury Publ., in press, 2019, pp. 284-331. 
17. Josephus (Flavius Josephus). Jewish Antiquities. Marcus R.; Wikgren A. (transl.). Loeb Classical Library, Cambridge, Harvard University Press Publ., 2001.

18. Lawrence A. W. Greek Architecture. $5^{\text {th }}$ ed., rev. R. W. Tomlinson. New Haven; London, Yale University Press Publ., 1996. 243 p.

19. Livy (T. Livius Patavinus). Ab Urbe Condita Libri.

20. Mackay C. S. The Breakdown of the Roman Republic: From Oligarchy to Empire. Cambridge; New York, Cambridge University Press Publ., 2009. 445 p.

21. Martin R. Greek Architecture. New York, Phaidon Press-Electa Publ., 2004. 204 p.

22. Marzano A. Roman Villas in Central Italy: A Social and Economic History. Leiden, Brill Publ., 2007. 823 p.

23. McKenzie J. The Architecture of Alexandria and Egypt. New Haven; London, Yale University Press Publ., 2007. $458 \mathrm{p}$.

24. McKenzie J. The Architecture of Petra. Oxford, Oxford University Press Publ., 1990. 209 p.

25. Netzer E. The Architecture of Herod, the Great Builder. Tübingen, Mohr Sieback Publ., 2006. 443 p.

26. Nielsen I. Hellenistic Palaces: Tradition and Renewal. Aarhus, Aarhus University Press Publ., 1994. 344 p.

27. Pandermalis D. Beobachtungen zur Fassadenarchitektur und Aussichtsveranda in hellenistischen Makedonien. Zanker P. (ed.). Hellenismus in Mittelitalien. Göttingen, Vandenhoeck und Ruprecht Publ., 1976, pp. 387-395 (in German).

28. Pandermalis D. E Keramose tou anaktorou ste Bergina. AMETOS II, Thessaloniki, 1987, pp. 579-605 (in Greek).

29. Pliny (the Elder, C. Plinius Secundus). Natural History. Rackham H. (transl.). Loeb Classical Library, Cambridge, Harvard University Press Publ., 1942. 672 p.

30. Senseney J. Adrift Toward Empire: The Lost Porticus Octavia in Rome and the Origins of the Imperial Fora. Journal of the Society of Architectural Historians, 2011, vol. 70, no. 4, pp. 421-441.

31. Steinby E. M. Edilizia Pubblica e Potere Politico nella Roma Repubblicana. Milano, Jaca Publ., 2012. 122 p. (in Italian).

32. Steinby E. M. (ed.). Lexicon Topographicum Urbis Romae, 6 vols. Rome, Edizioni Quasar Publ., 1995 (in Italian).

33. Strabo. Geographika (The Geography). Jones H. L. (transl.). Loeb Classical Library, Cambridge, Harvard University Press Publ., 1923. 496 p.

34. Watts E. J. Mortal Republic: How Rome Fell Into Tyranny. New York, Basic Books-Hachette Publ., 2018. $352 \mathrm{p}$.

35. Vitruvius. Ten Books on Architecture. Rowland I. D.; Howe Th. N. (trans., illus., and commentary). Cambridge; New York, Cambridge University Press Publ., 1999. 333 p.

36. Ward-Perkins J.; Boethius A. Etruscan and Roman Architecture. Harmondsworth, Penguin Books Publ., 1970. $622 \mathrm{p}$.

37. Welch K. A New View of the Origins of the Basilica: The Atrium Regium, Graecostasis, and Roman Diplomacy. Journal of Roman Archaeology, 2003, vol. 16, pp. 5-34.

38. Zarmakoupi M. Designing for Luxury on the Bay of Naples: Villas and Landscapes (c. 100 BCE - 79 CE). Oxford, Oxford University Press Publ., 2014. 352 p.

39. Zarmakoupi M. Private Villas, Italy and the Provinces. Ulrich R. B., Quenemon C. K. (eds.). A Companion to Roman Architecture. Chichester, Wiley-Blackwell Publ., 2014, pp. 362-380.

Title. The Development of Panoramic Sensibilities in Art, Literature, Architecture and Gardens in the Villas of Rome in the Late Republic and Early Empire: The Perspective from Stabiae.

Author. Thomas Noble Howe - Professor of Art and Art History, Scientific Director of the Restoring Ancient Stabiae Foundation, Via Salario, 12, Castellammare di Stabia 80053 Napoli, Italy. howethowethowethowet@gmail.com, howet@southwestern.edu

Abstract. This paper proposes that the highly innovative panoramic cross-axial architectural compositions in Roman monumental and villa architecture come about very rapidly in stages from mid- $3^{\text {rd }}$ to late $1^{\text {st }}$ centuries B.C. in a world in which a very mobile and cosmopolitan Roman senatorial elite and a Hellenistic royal elite, with their professional staffs, formed a unitary, multi-polar international culture. The development of axial compositions, vs. mid-space compositional volumes of classical Greece, began in the 280s in Ptolemaic Egypt with Greek forms modified by influence of New Kingdom axial sanctuaries. From the mid- $3^{\text {rd }}$ to mid- $2^{\text {nd }}$ centuries enclosed agorai and sanctuaries develop cross-axial, often outward-facing panoramic designs (Lindos, Kos, Pergamon). From mid- $2^{\text {nd }}$ century, the innovative energy, the resources, and sometimes 
the architects, pass to the intensely competitive political environment of the Late Roman Republic (after Pydna in 168 and the sieges of Corinth and Carthage in 146 B.C.). Axial, and soon cross-axial sanctuary and forum designs proliferate (Porticus Metelli, Gabii, Tivoli, Praenest, Forum of Caesar), usually in part inwardfacing, sometimes outward facing and panoramic (Praeneste, Tivoli). Such large compositions begin to affect large villa design by mid- $1^{\text {st }}$ century (Villa of the Papyri) and only after c. 50-30 B.C. panoramic outwardfacing colonnaded designs begin to be seen in architectural vignettes in wall painting (Villa San Marco, Stabiae), and actual villas (later additions to Oplontis, modifications and new villas at Stabiae, at the same time that there is an intense interest in elegiac landscape painting (Odyssey landscapes) and bucolic nature (Virgil, Georgics, c. 29 B.C.). The phenomenon seems to be a unified Mediterranean wide feature of elite culture since the same begins to be seen at Masada and Caesarea Maritima after Actium (31 B.C.)

Keywords: Roman villa; Hellenistic architecture; panoramic design; landscape painting; Stabiae.

Название статьи. Идея «панорамности» в искусстве, литературе, архитектуре и пространственной организации римских вилл в поздней Республике и ранней Империи: взгляд из Стабий.

Сведения об авторе. Хоу Томас Нобл - профессор, научный директор Фонда реставрации древних Стабий, Кастелламаре ди Стабиа, Виа Саларио, 12 , 80053 Неаполь, Италия. howethowethowethowet@gmail.com, howet@southwestern.edu

Аннотация. Одним из стремительно развивающихся новшеств в римской монументальной архитектуре середины III - конца I в. до н. э. становятся панорамные «перекрестноосевые» композиции. В это время мобильная, космополитически ориентированная римская сенаторская элита и эллинистические дворы с их «штатом» профессиональных мастеров формируют единую мультиполярную интернациональную культуру. Осевые построения, в противоположность сгруппированным вокруг центральных объемов ансамблям классической Греции, получают развитие в птолемеевском Египте начиная с 280-х гг. до н. э. под влиянием архитектуры эпохи Нового Царства. В середине III - середине II в. до н. э. эллинистические агоры и святилища подчиняются осевым, обращенным вовне панорамным композициям (Линдос, Кос, Пергам). Со временем эти новаторские приемы, а также финансовые ресурсы и отчасти мастера перемещаются в среду римской конкурирующей политической элиты поздней Республики (после битвы при Пидне 168 г. до н. э., а также осады Коринфа и Карфагена в 146 г. до н. э.). Множатся осевые, а затем и перекрестноосевые композиции святилищ и форумов (Габии, Тиволи, Пренесте и др.). К середине I в. до н. э. подобные проекты начинают оказывать влияние на архитектурное решение крупных вилл (вилла Папирусов), после 50-30 гг. до н. э. панорамные, обращенные вовне обрамляющие колоннады появляются в стенных росписях (вилла Сан-Марко в Стабиях), а также в реальной архитектуре вилл (Оплонтис, Стабии). В то же время наблюдается интерес к элегической пейзажной живописи (так называемые «пейзажи Одиссея») и буколической поэзии (Вергилий, Георгики, 29 г. до н. э.). Проявление того же феномена, очевидно, общего для всей средиземноморской элитной культуры, мы находим в Масаде и Кесарии в Палестине после битвы при Акции.

Ключевые слова: римская вилла; эллинистическая архитектура; панорамные композиции; пейзажная живопись; Стабии. 


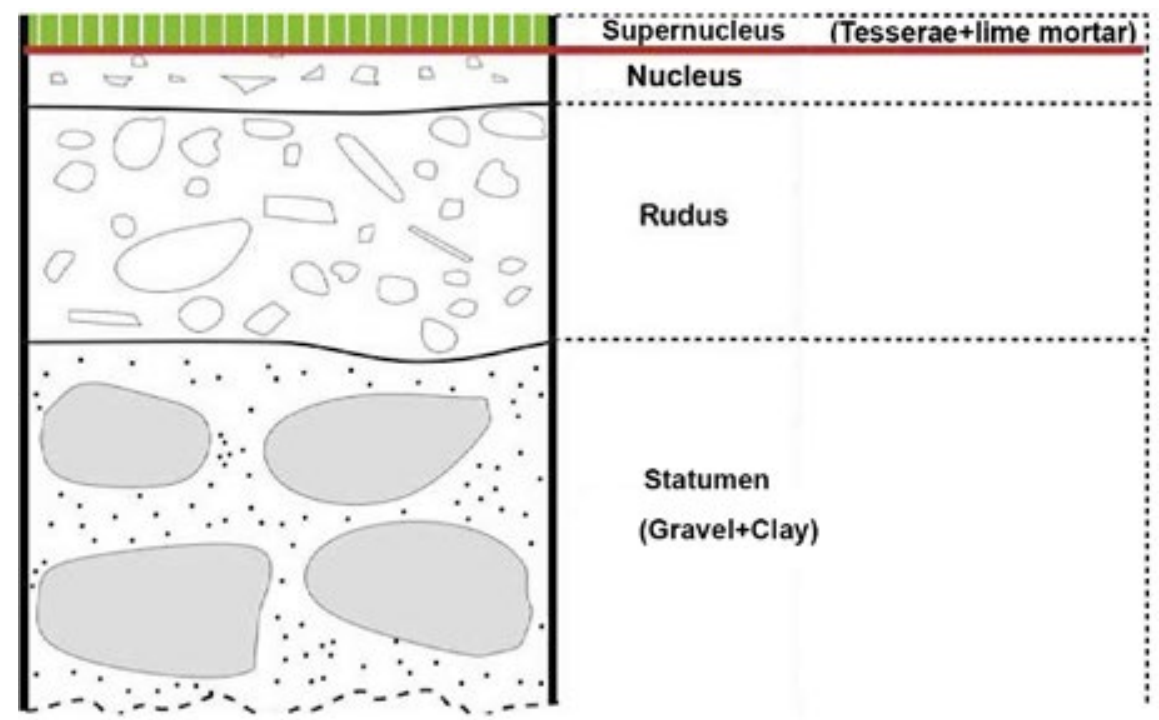

III. 15. Detailed diagram of the Lod pavement stratigraphic section.

Sketch by A. P. Frolov, with the kind permission granted by J. Neguer

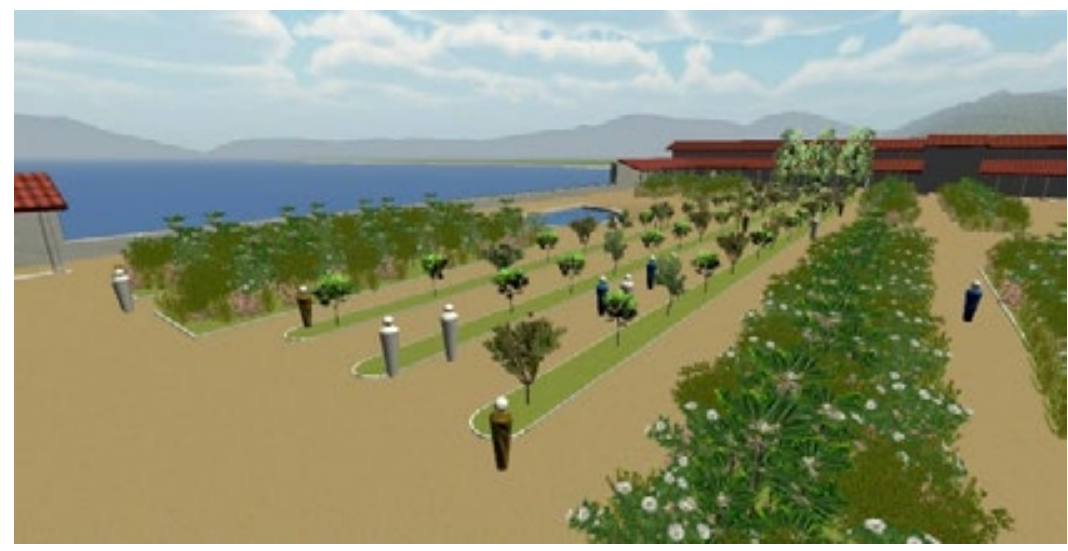

III. 16. Stabiae, Reconstruction of the Garden of the Villa Arianna. RAS Foundation / Prof. K. L. Gleason 